\title{
Progeny Testing and Selection Intensity for Holstein Bulls in Different Countries
}

\author{
R. L. Powell, H. D. Norman, and A. H. Sanders \\ Animal Improvement Programs Laboratory \\ Agricultural Research Service, USDA, Beltsville, MD 20705-2350
}

\begin{abstract}
International Bull Evaluation Service (Interbull) Holstein evaluations from February 1995 through February 2003 were used to determine characteristics of progeny testing for Holstein bulls in Australia, Canada, Denmark, France, Germany, Italy, New Zealand, Sweden, The Netherlands, and the United States. The decision to graduate a bull from progeny test (PT) was assumed to have been made based on the second Interbull evaluation, and graduation was defined as the addition of 200 daughters in the period 2.5 to $4.5 \mathrm{yr}$ later. Mean bull age at PT decision varied across countries by 12 mo. Mean numbers of herds and daughters ranged from 39 to 111 and 54 to 144, respectively. Countries with higher requirements for official evaluations generally had more herds and daughters but older bulls at PT decision. Mean estimated breeding values for yield traits of sires of tested bulls were most similar across countries for fat, differing by only $6.4 \mathrm{~kg}$. The four countries highest for sire protein differed only by $1 \mathrm{~kg}$; however, the range was $12 \mathrm{~kg}$. Percentages of bulls graduated ranged from 4.4 to 14.7 across countries. Selection intensities (standardized selection differentials) tended to be about 1.0 for yield traits. Selection intensities for somatic cell score were generally unfavorable, reflecting selection for negatively correlated yield traits. Reflecting variation in national breeding goals, selection intensities for stature were positive for most countries and highly negative for New Zealand. Selection intensity for fore udder was generally the lowest among the traits examined. All but one country showed positive selection for udder support. These statistics permit comparison of the components of PT programs across country, illustrating possible opportunities for improvement.
\end{abstract}

(Key words: genetic evaluation, progeny testing, selection intensity)

\footnotetext{
Received December 31, 2002.

Accepted May 7, 2003.

Corresponding author: R. L. Powell; e-mail: rpowell@aipl. arsusda.gov.
}

\begin{abstract}
Abbreviation key: Interbull $=$ International Bull Evaluation Service, MGS = maternal grandsire, $\mathbf{P T}=$ progeny test.
\end{abstract}

\section{INTRODUCTION}

Genetic progress in dairy cattle is largely determined by the merit of bulls used as sires of each generation. The merit of these sires is impacted by the combination of the pedigree merit of parents, number of bulls sampled, speed, and accuracy of the progeny test (PT), intensity of selection following the test, and maximum use of the best of the retained bulls. The processes of progeny testing usually necessitate certain tradeoffs or compromises. For example, when a fixed number of breedings are available for PT bulls, fewer bulls can be sampled with higher accuracy (more daughters), or more bulls can be sampled with lower accuracy. Sampling programs could achieve comparable results by selecting the pool of PT bulls based on high pedigree requirements, then returning to service a higher proportion of bulls, or by sampling a larger number of bulls based on lower pedigree requirements but culling more heavily following PT. Thus, it is not possible to evaluate the testing program of an organization or a country by a single factor.

The rate of genetic gain for US Holsteins increased considerably beginning in the late 1960s (Powell et al., 1977; Lee et al., 1985). Powell and Norman (1990) showed a relationship between improvements in evaluation methodology and rate of Holstein genetic improvement for yield, but at the same time, the number of bulls sampled was steadily rising (Norman et al., 2001). Defining bulls as returned to service that doubled their number of daughters since PT, Norman et al. (2002) found that $12 \%$ of Holsteins were selected from PT programs in the United States.

Van Tassell and Van Vleck (1991) investigated weighted selection differentials for yield in the four paths of selection (sires and dams of bulls and sires and dams of cows) for births in the mid to late 1970s in the Northeastern United States. For sires of bulls, weighted selection differential was approximately equal to the potential, based on merit of available ani- 
mals. In all other paths, actual selection differentials were far below the potential. Most disappointing was the merit for sires of cows, which were selected with only one third of the potential differential. Only AI sires were considered, and the inclusion of non-AI sires of cows would likely produce an even bleaker picture.

The objective of this study was to document the nature of national sampling programs, including numbers of bulls, herds, daughters, and reliability and to compute the selection intensities for yield and some health and conformation traits. Differential usage of the best bulls is a key to genetic improvement in a population. However, this study focused on national PT programs that create and identify the best bulls, not how those bulls are used.

\section{MATERIALS AND METHODS}

Data were International Bull Evaluation Service (Interbull) evaluations for Holstein bulls for February and August from 1995 through February 2003. Countries included were Australia, Canada, Denmark, France, Germany, Italy, New Zealand, Sweden, The Netherlands, and the United States. These evaluations were computed by the multiple-trait, across-country evaluation (i.e., MACE) method (Schaeffer, 1994).

An assumption was that the decision to return a bull to service (graduate) or cull was made at the time of his second appearance in the semiannual Interbull file (decision evaluation). Interbull began quarterly evaluations in November 1998, but only February and August evaluations were used in this study. Identification of second evaluations required the participation of the home country in the Interbull service for at least two prior runs (one without the young bull and the next with him included); thus, the earliest possible decision run was February 1996. New Zealand and Australia joined the service later and their first decision runs were August 1997 and February 1998, respectively.

Bulls were required to be less than $7 \mathrm{yr}$ old at the time of the decision evaluation. This prevented bulls that entered the Interbull data later in life from distorting results. Bulls less than 4 yr old were also excluded, as it was assumed any such bulls had incorrect birth dates. The country with the most daughters in the decision evaluation was considered the sampling (home) country. The 10 countries included had at least 150 PT bulls in the data. Number of bulls tested per year, mean age of PT bulls, and numbers of herds and daughters in decision evaluations were computed.

Bulls were considered to have returned to service (graduated from PT) if they added at least 200 daughters in the home country during the Interbull evaluations from 3 to $5 \mathrm{yr}$ after the initial evaluation (2.5 to
$4.5 \mathrm{yr}$ after the decision evaluation). The 3-yr lower limit was imposed to exclude daughters conceived before the availability of data based on performance of PT daughters. Evaluations through February 2003 were used to determine return to service. August 1998 was therefore the last decision run considered in this study (4.5 yr before February 2003). Because the 200daughter requirement might not fit all situations, other definitions (i.e., 100 and 500 daughters in the home country) for successful return to service were investigated.

The effectiveness of a PT program depends on the merit of bulls tested and the proportion graduated. Graduating a larger proportion of bulls might suggest a less rigorous program, but if bulls entering PT were highly selected for pedigree, the effectiveness could be higher in terms of the merit of the graduated bulls. Average yield merit for sires and maternal grandsires (MGS) of PT bulls was from February 1995 Interbull evaluations computed with essentially unity genetic correlations. Thus, the ranking of the bulls would be essentially the same on all national scales. For convenience, the US scale was chosen. Corresponding sire merit for conformation and udder health (SCS) were from the August 2001 and August 2002 evaluations, the earliest biannual evaluations for which all countries with data in this study participated.

The percentage of graduates, home-country EBV difference of graduates from all PT bulls (selection differential), and selection differential on a standardized basis (selection intensity) were computed for each decision evaluation run within each country. Results were pooled for each country, weighted by the number of bulls they included in each run. Standard deviations used in the standardization were from Interbull estimates of bull genetic standard deviations for each decision evaluation (Interbull, 1998 and corresponding prior printed documents for yield; Interbull, 2001 for conformation and Interbull, 2002 for SCS). These standard deviations are reported on a transmitting ability basis, so they were doubled for compatibility with the EBV data used in this study. Relative breeding values (reported to and received from the Interbull Centre for some countries) were decoded using equations provided by Interbull.

For yield traits, EBV were from the decision evaluation run. For conformation (stature, fore udder, and udder support) and udder health (SCS), evaluations were not available from the same runs as the decision evaluations, so EBV from the August 2001 and 2002 runs, respectively, were used. Interbull conformation evaluations were initiated only in August 1999, and not all countries in this study participated before May 2001. Udder health evaluations were initiated in May 
Table 1. Numbers of bulls and decision evaluation runs per country and means for numbers of herds, daughters, yield reliability, and bull age at decision run.

\begin{tabular}{lclcccc}
\hline Country & $\begin{array}{c}\text { Total } \\
\text { bulls }\end{array}$ & $\begin{array}{l}\text { Decision } \\
\text { runs }\end{array}$ & Herds & Daughters & Reliability & $\begin{array}{l}\text { Bull age } \\
(\mathrm{mo})\end{array}$ \\
\hline Australia & 158 & $2^{1}$ & 42 & 76 & 80 & 70 \\
Canada & 1295 & 6 & 61 & 70 & 86 & 69 \\
Denmark & 1055 & 6 & 80 & 92 & 88 & 67 \\
France & 1796 & 6 & 76 & 79 & 87 & 77 \\
Germany & 2258 & 6 & 78 & 108 & 90 & 73 \\
Italy & 872 & 6 & 54 & 70 & 85 & 65 \\
New Zealand & 419 & $3^{2}$ & -3 & 104 & 90 & 75 \\
Sweden & 279 & 6 & -3 & 144 & 91 & 67 \\
The Netherlands & 1152 & 6 & 111 & 127 & 92 & 80 \\
United States & 4393 & 6 & 39 & 54 & 80 &
\end{tabular}

\footnotetext{
${ }^{1}$ At that time, Australia was publishing genetic evaluations only one time per year. Thus, nearly all bulls had February decision runs.

${ }^{2}$ Because of seasonal breeding, most new bulls are added in August evaluations. Thus, the three runs provided nearly 2 yr of new bulls.

${ }^{3}$ New Zealand and Sweden did not report number of herds until 2000.
}

2001, but as of February 2003, New Zealand had not yet participated. May 2002 was the first run for which all other countries in this study participated.

For the SCS EBV, signs were reversed for some countries so that positive numbers were always desirable (e.g., positive selection represented improvement in udder health). For stature, positive selection intensities indicate selection for taller cows, the desirability of which differs by country.

\section{RESULTS AND DISCUSSION}

Table 1 shows the number of bulls, and mean number of herds, daughters, and reliability for yield traits, and mean age of bulls in the decision evaluation for the 10 countries included in the study. Number of decision evaluation runs included is also shown. Data were available for production traits from different numbers of runs depending on when countries joined the Interbull service. Because of the seasonal nature of New Zealand's breeding program, 410 of the 419 bulls included were from August decision evaluations (1997 and 1998), with the remaining nine coming in February 1998. Australia has a similar seasonality, but in 1997 and 1998 released only one set of evaluations per year such that their decision evaluations (bull's second biannual appearance) were predominantly in February 1998 with practically no additional bulls in August 1998. For the other eight countries, bulls per decision evaluation ranged from 25 to 878. Mean numbers of daughters and herds were lowest for the United States. Largest sampling groups were for The Netherlands, New Zealand, and Sweden. Mean reliability ranged from 80 to $92 \%$. Reliabilities are estimated in different ways and comparisons need to be made with caution.
Bulls were youngest at the decision evaluation (mean age 65 to $67 \mathrm{mo}$ ) for Denmark, New Zealand, The Netherlands, and the United States. Highest mean ages were for France $(77 \mathrm{mo})$ and Sweden $(75 \mathrm{mo})$. Timing of the decision evaluation as defined here is affected by the definition of official or publishable evaluations within the countries because evaluations must be publishable in the reporting country to be included in Interbull evaluations. Table 2 displays the official publication criteria for the evaluations considered for this study. France requires the greatest amount of information before publishing evaluations, so it was not surprising that French bulls are the oldest in PT decision evaluations. The French minimum of $70 \%$ reliability is based on daughters only. Sweden requires at least 15 daughters to have completed 305-d records. Because of

Table 2. National publication requirements for yield genetic evaluations during the progeny test period in this study.

\begin{tabular}{llllc}
\hline Country & Reliability & Herds $^{1}$ & Daughters & DIM \\
\hline Australia & 63 & 15 & & 6 \\
Canada & 60 & 10 & 20 & 90 \\
Denmark & 60 & & & 45 \\
France & $70^{2}$ & & & 60 \\
Germany & 70 & 20 & 35 & 100 \\
Italy & & 20 & & 60 \\
New Zealand & & & & 5 \\
Sweden & & & $15^{4}$ & 305 for $\geq 15$ \\
The Netherlands & 50 & 5 & 15 & $180^{5}$ \\
United States & & & 10 & 40 \\
\hline
\end{tabular}

${ }^{1}$ Interbull requires a minimum of 10 herds.

${ }^{2}$ Based on daughters only. Minimum is $60 \%$ if high enough in total merit index.

${ }^{3}$ All bulls with AI codes included.

${ }^{4}$ Required 15 effective daughters.

${ }^{5}$ Prior to November 1997 the days in milk requirement was 60. 
Table 3. Percentages of progeny tested bulls with sire evaluated by Interbull in February 1995 and mean sire EBV on US scale (from analysis with genetic correlations assumed near unity).

\begin{tabular}{|c|c|c|c|c|c|c|}
\hline \multirow[b]{2}{*}{ Country } & \multirow{2}{*}{$\begin{array}{l}\text { Total } \\
\text { bulls (no.) }\end{array}$} & \multirow{2}{*}{$\begin{array}{l}\text { Total sires } \\
\text { evaluated } \\
\text { (no.) }\end{array}$} & \multirow{2}{*}{$\begin{array}{l}\text { Bulls with } \\
\text { sire } \\
\text { evaluated } \\
(\%)\end{array}$} & \multicolumn{3}{|c|}{ Sire EBV $(\mathrm{kg})$} \\
\hline & & & & Milk & Fat & Protein \\
\hline Australia $^{1}$ & 158 & 25 & 98 & 876 & 24.1 & 36.7 \\
\hline Canada & 1295 & 84 & 100 & 606 & 23.3 & 25.6 \\
\hline Denmark & 1055 & 55 & 100 & 794 & 25.7 & 31.5 \\
\hline France & 1796 & 89 & 100 & 806 & 27.3 & 32.8 \\
\hline Germany & 2258 & 167 & 97 & 559 & 23.8 & 24.5 \\
\hline Italy & 872 & 93 & 100 & 774 & 25.3 & 31.0 \\
\hline New Zealand ${ }^{1}$ & 419 & 55 & 74 & 913 & 29.7 & 35.9 \\
\hline Sweden & 279 & 40 & 100 & 846 & 24.7 & 28.4 \\
\hline The Netherlands & 1152 & 95 & 93 & 842 & 27.5 & 36.2 \\
\hline United States & 4393 & 201 & 99 & 961 & 28.6 & 35.6 \\
\hline
\end{tabular}

${ }^{1}$ Australia and New Zealand were not included in the 1995 Interbull evaluations so only data on sires evaluated in other countries were available for this table. To account for their later entry into the Interbull service, an adjustment of 9 mo of US genetic trend was applied.

the time this takes, Swedish bulls were also older in PT decision evaluations. Conversely, New Zealand and the United States have low requirements for publication and among the lowest mean bull ages. In general, countries with lower publication requirements had younger bulls with fewer herds and daughters, and lower reliability. Even though New Zealand had low publication requirements, they still obtained many daughters and high reliability at an early age. This may be attributed to seasonal calving, which results in many daughters entering production recording within a short time. Although The Netherlands required records to be of at least $180 \mathrm{~d}$ for part of the time period studied, Dutch bulls were relatively young at the time of PT decision, indicating early distribution of young PT bull semen, quick use of semen in the field, or daughters calving at a young age.

If individual bulls sampled in a country have low pedigree merit, even a high cull rate may produce a bull battery of low genetic merit. Most of the sampled bulls had sires with February 1995 Interbull evaluations. Those evaluations did not limit the data to bulls born in the last $17 \mathrm{yr}$, a practice begun for Holsteins 2 yr later. Interbull does not have evaluations for dams of bulls, but most maternal grandsires had Interbull evaluations for yield. Because these evaluations were calculated with a genetic correlation of essentially unity, rankings were practically the same on every national scale. The US scale was chosen for reporting of mean sire merit (Table 3). The same six decision evaluation dates were used for eight countries. Australia and New Zealand had data available from only the latest two or three decision evaluation dates, respectively, thus the PT time period investigated was later by $9 \mathrm{mo}$, on average. Due to genetic trend in the available sire population, pedigree merit for bulls from these two countries would be expected to be slightly higher. To facilitate comparison, an adjustment for threefourths year of genetic trend was applied to the average sire EBV from these countries.

Percentages of PT bulls with available evaluations for sires from February 1995 were very high except for New Zealand. Because New Zealand was not part of Interbull evaluations in 1995, only bull sires evaluated elsewhere were available (74\%). Although Australia also was not part of the Interbull service in 1995, 98\% of bull sires had been evaluated elsewhere. Overall, mean sire EBV ranges were $402 \mathrm{~kg}$ of milk, $6.4 \mathrm{~kg}$ of fat, and $12.2 \mathrm{~kg}$ of protein. Given the range in milk and applying typical component percentages, it appears that pedigree selection for fat was more similar across countries than for milk or protein. Sire merit tended to be highest for bulls from Australia (except for fat), New Zealand, The Netherlands, and the United States and lowest for Canada and Germany.

For sires of bulls, there is more opportunity for worldwide selection than exists for dams of bulls. Merit of bull dams likely differs more across countries than does merit of bull sires. The ranges in mean MGS merit was much larger (Table 4) than for sires. The high countries again were Australia, The Netherlands, and the United States, with Germany and Sweden having the lowest averages.

Corresponding sire data for SCS and conformation traits were available only from more recent evaluations. Due to the 17-yr time window, most of the bulls studied had no Interbull evaluation for sire or MGS. Even restricting bulls to those with 1998 decision runs, only about two-thirds of sires had evaluations (Table 5). Because the US scale was used for all countries, the sign for SCS EBV were not reversed, thus lower numbers are preferred. Lower sire SCS EBV were for bulls from 
Table 4. Percentages of progeny tested bulls with maternal grandsire (MGS) evaluated by Interbull in February 1995 and mean MGS EBV on US scale (from analysis with genetic correlations assumed near unity).

\begin{tabular}{lllrrr}
\hline & \multirow{2}{*}{$\begin{array}{l}\text { Total } \\
\text { bulls (no.) }\end{array}$} & $\begin{array}{l}\text { Bulls with } \\
\text { MGS evaluated } \\
(\%)\end{array}$ & Milk & Fat & Protein \\
\cline { 4 - 6 } Country & 158 & 70 & 505 & 20.7 & 21.3 \\
\hline Australia $^{1}$ & 1295 & 95 & 117 & 12.9 & 8.3 \\
Canada & 1055 & 99 & 46 & 13.8 & 7.9 \\
Denmark & 1796 & 97 & 455 & 22.1 & 18.5 \\
France & 2258 & 93 & -284 & 7.4 & 0.1 \\
Germany & 872 & 92 & 556 & 20.8 & 22.0 \\
Italy & 419 & 57 & 376 & 21.9 & 17.7 \\
New Zealand & 1 & 90 & -73 & 10.7 & 3.8 \\
Sweden & 279 & 95 & 531 & 28.3 & 23.9 \\
The Netherlands & 1152 & 99 & 776 & 29.7 & 25.0 \\
United States & 4393 & &
\end{tabular}

\footnotetext{
${ }^{1}$ Australia and New Zealand were not included in the 1995 Interbull evaluations so only data on MGS evaluated in other countries were available for this table. To account for their later entry into the Interbull service, an adjustment of 9 mo of US genetic trend was applied.
}

Canada and the United States, and higher SCS EBV were from France, Italy, New Zealand, Sweden, and The Netherlands (all 3.20 to 3.24). Sires for taller cattle were favored by Canada and Denmark, and sires for shorter cattle were especially favored by Sweden and somewhat for New Zealand and the United States. These sires may have been selected primarily for other traits, so cautious interpretation is warranted. Also, in many cases, only a few sires were involved, thus the impact of individual sires on averages can be substantial.

Percentage of bulls graduated is impacted by the decision criteria chosen (Table 6). Defining graduation from PT by the addition of 100 daughters resulted in an average graduation rate of $8.3 \%$ across countries, compared to $7.1 \%$ for 200 and $5.3 \%$ for 500 daughters. Pooled graduation rates (total graduates/total sampled) were higher at 9.5, 8.0, and 5.9\%, suggesting that countries with more tested bulls graduated a higher fraction.
Graduation rates in New Zealand, Sweden, and The Netherlands were much less impacted by graduation definition than in other countries. Definition had a larger impact for Germany and Italy. Ranking of countries by percent graduated was similar across definitions, with Australia, Canada, and Denmark graduating the lowest percentages and France, Germany, and New Zealand graduating the highest percentages. Selection intensities were investigated using the 200daughter definition.

Percentage of bulls graduating from PT ranged from 4.4 to $14.7 \%$ (Table 7 ). The relatively high percentage of bulls graduating in Germany (14.7) is supported by Swalve and Höver (2003), who reported a graduation rate of $15.3 \%$. They found that although many German bulls get a second-crop of daughters, most are used sparingly. When they required 500 added daughters, graduation rate dropped dramatically. However, determining graduation rate was not a main objective of

Table 5. Percentages of bulls with progeny test decisions made in 1998 having sires evaluated by Interbull for SCS in August 2002 and mean sire EBV for SCS on the U.S. scale; and percentages of bulls with progeny test decisions made in 1998 having sires evaluated by Interbull for selected conformation traits in August 2001 and mean sire EBV for those traits on the U.S. scale.

\begin{tabular}{|c|c|c|c|c|c|c|c|c|}
\hline \multirow[b]{3}{*}{ Country } & \multirow[b]{3}{*}{$\begin{array}{l}\text { Total } \\
\text { bulls (no.) }\end{array}$} & \multirow[b]{3}{*}{$\begin{array}{l}\text { Total sires } \\
\text { evaluated (no.) }\end{array}$} & \multicolumn{2}{|l|}{ SCS } & \multicolumn{4}{|c|}{ Conformation traits } \\
\hline & & & \multirow{2}{*}{$\begin{array}{l}\text { Bulls with } \\
\text { sire evaluated } \\
(\%)\end{array}$} & \multirow[b]{2}{*}{$\begin{array}{l}\text { Sire } \\
\text { EBV }\end{array}$} & \multirow{2}{*}{$\begin{array}{l}\text { Bulls with } \\
\text { sire evaluated } \\
(\%)\end{array}$} & \multicolumn{3}{|c|}{ Sire EBV } \\
\hline & & & & & & Stature & $\begin{array}{l}\text { Fore } \\
\text { udder }\end{array}$ & $\begin{array}{l}\text { Udder } \\
\text { support }\end{array}$ \\
\hline Australia & 158 & 15 to 16 & 81 & 3.16 & 81 to 84 & -0.03 & -0.45 & 0.09 \\
\hline Canada & 419 & 17 & 73 & 3.02 & 73 & 0.87 & -0.06 & 0.40 \\
\hline Denmark & 781 & 8 to 9 & 62 & 3.09 & 62 & 0.51 & -0.03 & 0.21 \\
\hline New Zealand & 333 & 11 to 15 & 59 & 3.20 & 87 & -0.14 & -0.13 & -0.32 \\
\hline Sweden & 162 & 4 & 67 & 3.23 & 64 & -1.00 & -0.49 & -0.74 \\
\hline The Netherlands & 81 & 41 to 51 & 89 & 3.24 & 86 to 88 & 0.25 & -0.28 & -0.10 \\
\hline United States & 1517 & 62 to 64 & 75 & 3.05 & 75 & -0.17 & -0.09 & -0.12 \\
\hline
\end{tabular}


Table 6. Percentage of bulls graduating from progeny testing based on various criteria for addition of daughters from 3 to $5 \mathrm{yr}$ after first evaluation.

\begin{tabular}{lccc}
\hline & \multicolumn{2}{c}{ Bulls retained (\%) } \\
\cline { 2 - 4 } & $\begin{array}{l}\text { With } \geq 100 \\
\text { daughters } \\
\text { added }\end{array}$ & $\begin{array}{l}\text { With } \geq 200 \\
\text { daughters } \\
\text { added }\end{array}$ & $\begin{array}{c}\text { With } \geq 500 \\
\text { daughters } \\
\text { added }\end{array}$ \\
\hline Australia & 5.7 & 4.4 & 1.9 \\
Canada & 5.6 & 4.5 & 3.4 \\
Denmark & 5.7 & 4.5 & 3.1 \\
France & 9.4 & 8.1 & 6.7 \\
Germany & 17.3 & 14.7 & 10.4 \\
Italy & 9.2 & 7.0 & 4.8 \\
New Zealand & 9.3 & 9.8 & 8.4 \\
Sweden & 10.3 & 5.0 & 4.7 \\
The Netherlands & 5.7 & 5.6 & 4.4 \\
United States & 6.0 & 7.5 & 5.2 \\
Average across countries & 9.0 & 7.1 & 5.3 \\
Average across all bulls & 8.3 & 8.0 & 5.9 \\
\hline
\end{tabular}

their study, and not all bulls had an opportunity for large numbers of second-crop daughters. Selection intensities for yield (Table 7) tended to be around 1.0 but ranged from 0.56 to 1.51 . Means across countries were 0.91 for milk, 0.84 for fat, and 1.17 for protein. The relatively low selection intensity for milk in The Netherlands (0.66) was expected because their total merit index included one of the larger negative weights for milk (International Bull Evaluation Service, 1992). Table 8 shows the results of a survey of the participating countries regarding their total merit indexes at the time of the decision runs in this study. The countries giving heavy negative weights to milk volume generally had the lowest calculated intensities for milk. This demonstrates that it is not possible to rank the success of PT programs based only on the magnitude of selection intensities for individual traits. The relative importance of traits in the national program must be considered. For all 10 countries, the highest selection intensity was for protein, and the selection intensity for fat was lowest for six of the countries. Australia and Sweden retained a low percentage of tested bulls and had the highest selection intensities across the three yield traits (Table 7). These two countries had the fewest bulls tested, which raises the possibility that chance affected results. Relative emphases on different traits in various national indexes in 2002 are summarized by VanRaden (2002), and all have changed since the decision times of this study.

Table 9 shows the selection intensities for SCS and three conformation traits. Nearly all bulls had SCS evaluations in August 2002. For ease of comparison, SCS evaluations from countries where negative numbers indicate reduced SCS were reversed in sign; for all countries, positive numbers represent improvement. In Denmark, Italy, and The Netherlands, PT graduates show selection for improved SCS. Danish improvement can be attributed to the inclusion of udder health in the national index (Table 8); however, Sweden also included SCS and selection intensity was neutral regarding SCS.

Table 7. Number and percentage of bulls graduating from progeny testing ( $\geq 200$ daughters added between 3 and 5 yr after first evaluation) and pooled ${ }^{1}$ selection intensities by country.

\begin{tabular}{lrrrrrr}
\hline & \multicolumn{2}{c}{ Retained } & & \multicolumn{3}{c}{ Selection intensities } \\
\cline { 2 - 3 } Country & $($ No. $)$ & $(\%)$ & & Milk & Fat & Protein \\
\hline Australia & 7 & 4.4 & & 1.05 & 1.06 & 1.26 \\
Canada & 58 & 4.5 & & 0.99 & 0.56 & 1.06 \\
Denmark & 47 & 4.5 & & 1.02 & 0.89 & 1.23 \\
France & 146 & 8.1 & & 0.93 & 0.88 & 1.31 \\
Germany & 331 & 14.7 & & 0.80 & 0.82 & 0.96 \\
Italy & 61 & 7.0 & & 0.88 & 0.79 & 1.10 \\
New Zealand & 41 & 9.8 & & 0.73 & 0.81 & 1.19 \\
Sweden & 14 & 5.0 & 1.19 & 0.91 & 1.51 \\
The Netherlands & 65 & 5.6 & 0.62 & 1.02 & 1.10 \\
United States & 328 & 7.5 & & 0.91 & 0.64 & 0.97 \\
Overall across countries & 1098 & 7.1 & & 0.91 & 0.84 & 1.17 \\
\hline
\end{tabular}

${ }^{1}$ Mean of selection intensities for decision runs weighted by number of bulls sampled. 
Table 8. National selection indexes and weights of traits used for progeny test selections reviewed in this study.

\begin{tabular}{llrrlllr}
\hline Country & Index & Milk & Fat & Protein & $\begin{array}{r}\text { Udder } \\
\text { health }\end{array}$ & Type $^{1}$ & Other \\
\hline Australia & ASI & -23 & 28 & 49 & & & \\
Canada & LPI & 0 & 11 & 49 & & 40 & \\
Denmark & S-index & -3 & 9 & 18 & 12 & 34 & 24 \\
France & ISU & -20 & 0 & 50 & & 25 & 5 \\
Germany & RZM & 0 & 20 & 80 & & 20 & \\
Italy & ILQM & -21 & 5 & 54 & & 22 & 41 \\
New Zealand & BWI & -22 & 10 & 44 & & \\
Sweden & TMI & 0 & 0 & 27 & & 33 & \\
The Netherlands & INET & -25 & 14 & 61 & & & \\
United States & TPI & 0 & 17 & 50 & & & \\
\hline
\end{tabular}

${ }^{1}$ Some elements of conformation.

${ }^{2}$ Included 20 against body size.

Because the Italian genetic evaluations for SCS began only in late 2001, the improvement seen occurred for unknown reasons. For the other seven countries, graduates had poorer SCS evaluation on average than for all PT bulls, although with the exception of Australia, the negative intensities were small.

As with SCS, conformation evaluations used to calculate selection intensities were not from the decision evaluations. Nearly all bulls had conformation evaluations except for Australia and Sweden. In calculating these selection intensities, it is assumed that the merit of the bulls without conformation evaluations was similar to that for bulls with conformation evaluations. Due to the negative emphasis on cow size in the national index, it was not surprising that bulls returned to service in New Zealand had lower evaluations for stature. Graduates sired taller cows in Canada, Denmark, France, Italy, and The Netherlands. Emphasis on stature was nearly neutral for Australia, Sweden, and the United States.
Selection intensity for fore udder tended to be small for most countries and averaged 0.07. Canada and Italy placed the most emphasis on fore udder, and graduates in Australia were 0.23 standard deviations below the average for all bulls tested. For udder support, selection intensity was highest in Canada and Italy and averaged 0.14 across countries. Selection intensities for udder support were the most uniform with seven of 10 between 0.06 and 0.17. Only for New Zealand were PT graduates slightly lower relative to all bulls they sampled. For these selected conformation traits, Canada and Italy clearly placed the most emphasis. Some other countries had as much or more weight on conformation in the national index, but that may have been on other conformation characteristics or the national indexes may not have been followed when graduating PT bulls.

It is somewhat risky to focus on the selection achieved in individual traits in various countries as they have different selection goals; however, some general comments can be made. Italy appears to have been fortu-

Table 9. Pooled selection intensities by country for SCS and three conformation traits.

\begin{tabular}{|c|c|c|c|c|c|c|c|c|}
\hline \multirow[b]{3}{*}{ Country } & \multicolumn{3}{|c|}{$\operatorname{SCS}^{1}$} & \multicolumn{5}{|c|}{ Conformation } \\
\hline & \multirow{2}{*}{$\begin{array}{l}\text { Bulls } \\
\text { evaluated } \\
\text { (No.) }\end{array}$} & \multirow{2}{*}{$\begin{array}{l}\text { Bulls } \\
\text { retained } \\
\text { (No.) }\end{array}$} & \multirow[b]{2}{*}{$\begin{array}{l}\text { Selection } \\
\text { intensity }\end{array}$} & \multirow{2}{*}{$\begin{array}{l}\text { Bulls } \\
\text { evaluated } \\
\text { (No.) }\end{array}$} & \multirow{2}{*}{$\begin{array}{l}\text { Bulls } \\
\text { retained } \\
\text { (No.) }\end{array}$} & \multicolumn{3}{|c|}{ Selection intensity } \\
\hline & & & & & & Stature & Fore udder & $\begin{array}{l}\text { Udder } \\
\text { support }\end{array}$ \\
\hline Australia & 158 & 7 & -0.42 & 77 & 7 & -0.01 & -0.23 & 0.08 \\
\hline Canada & 1295 & 58 & -0.12 & 1291 & 58 & 0.28 & 0.25 & 0.42 \\
\hline Denmark & 1055 & 47 & 0.12 & 1050 & 47 & 0.31 & 0.05 & 0.14 \\
\hline France & 1796 & 146 & -0.07 & $1792^{2}$ & 146 & 0.21 & 0.02 & 0.11 \\
\hline Germany & 2253 & 330 & -0.04 & 2137 & 330 & 0.14 & 0.12 & 0.07 \\
\hline Italy & 872 & 61 & 0.55 & 872 & 61 & 0.27 & 0.29 & 0.28 \\
\hline New Zealand & - & - & - & 363 & 40 & -0.20 & -0.01 & -0.05 \\
\hline Sweden & 275 & 14 & -0.01 & 98 & 13 & 0.00 & -0.07 & 0.17 \\
\hline The Netherlands & 1152 & 65 & 0.28 & $1135^{2}$ & 65 & 0.20 & 0.15 & 0.12 \\
\hline United States & 4392 & 328 & -0.11 & 3932 & 328 & 0.06 & 0.09 & 0.06 \\
\hline
\end{tabular}

${ }^{1}$ Signs were reversed for SCS on some nationals scales so positive intensities indicate improvements.

${ }^{2}$ Only 1034 French bulls and 706 Dutch bulls were evaluated for fore udder. 
nate in the SCS merit of graduates and placed considerable emphasis on conformation traits, as all selection intensities were 0.27 or more. In contrast, German, Swedish, and US graduates differed little from the whole PT group for these traits. Their goals may have been simply to maintain these traits while emphasizing others. For the United States, average pedigree merit of PT bulls was among the highest, but selection intensities for yield traits were moderate. German PT bulls had the lowest average pedigree merit, and a large percentage of these bulls were graduated based on the definition imposed.

\section{CONCLUSIONS}

Speed and accuracy of bull sampling are affected by the requirements for official bull evaluations. More rigorous publication requirements lead to older bulls with higher reliability at first official evaluation. Merit of PT bull sires varied by country. The pedigree merit of bulls in the PT program may influence the graduation rate and the relative merit of graduates compared with bulls culled after PT.

The percentage of bulls graduated from PT varied widely across countries. In general, graduating a lower proportion of PT bulls would indicate desirable selection, but it is important that the group of bulls graduated represent the best of those sampled. Selection intensities for yield traits tended to be about 1.0, with some exceptions. Success of PT programs cannot be easily compared across countries. Countries have differing breeding goals, and these goals change over time; national total merit indexes changed in all countries from those in this study to more recent ones reported by VanRaden (2002).

Some results were particularly instructive in demonstrating the differences in breeding goals. Graduated Dutch bulls had the lowest selection intensities for milk among the countries and New Zealand graduates had negative EBV for stature. These values clearly reflect the breeding goals of these countries. Statistics pre- sented permit comparison of the components of progeny test programs across country, indicating the differences being achieved in that element, thereby illustrating opportunities for improvement.

\section{ACKNOWLEDGMENTS}

The cooperation of the national evaluation centers providing the data to Interbull is acknowledged.

\section{REFERENCES}

International Bull Evaluation Service. 1992. Sire evaluation procedures for dairy production traits practiced in various countries, 1992. Bulletin 5, International Bull Evaluation Service, Uppsala, Sweden.

International Bull Evaluation Service. 1998. INTERBULL routine genetic evaluation for dairy production traits, August 1998. http:// www-interbull.slu.se/eval/framesida-prod.htm. Accessed July 9, 2002.

International Bull Evaluation Service. 2001. INTERBULL routine genetic evaluation for conformation traits, May 2001. http://wwwinterbull.slu.se/eval/framesida-prod.htm. Accessed July 9, 2002.

International Bull Evaluation Service. 2002. INTERBULL routine genetic evaluation for udder health traits, May 2002. http://wwwinterbull.slu.se/eval/framesida-prod.htm. Accessed July 9, 2002.

Lee, K. L., A. E. Freeman, and L. P. Johnson. 1985. Estimation of genetic change in the registered Holstein cattle population. J. Dairy Sci. 68:2629-2638.

Norman, H. D., R. L. Powell, J. R. Wright, and C. G. Sattler. 2001. Overview of progeny-test programs of artificial-insemination organizations in the United States. J. Dairy Sci. 84:1899-1912.

Norman, H. D., R. L. Powell, J. R. Wright, and C. G. Sattler. 2003. Timeliness of progeny testing through artificial insemination and percentage of bulls returned to service. J. Dairy Sci. 86:15131525.

Powell, R. L., and H. D. Norman. 1990. Impact of changes in genetic improvement programs and annual cycles on Holstein service sire merit. J. Dairy Sci. 73:1123-1129.

Powell, R. L., H. D. Norman, and F. N Dickinson. 1977. Trends in breeding value and production. J. Dairy Sci. 60:1316-1326.

Swalve, H. H., and K. Höver. 2003. Examinations using the results of breeding value estimation for Holstein sires and cows in Germany. Arch. Tierz. 46:113-126.

Schaeffer, L. R. 1994. Multiple-country comparison of dairy sires. J. Dairy Sci. 77:2671-2678.

Van Tassell, C. P., and L. D. Van Vleck. 1991. Estimates of genetic selection differentials and generation intervals for four paths of selection. J. Dairy Sci. 74:1078-1086.

VanRaden, P. M. 2002. Selection of dairy cattle for lifetime profit. Proc. 7th World Congr. Genet. Appl. Livest. Prod. 29:127-130. Montpellier, France, Aug. 19-23, 2002. 